\title{
CHANGING PEOPLE'S PREFERENCES BY THE STATE AND THE LAW
}

\begin{abstract}
Ariel Porat ${ }^{*}$
In standard economic models, two basic assumptions are made: the first, that actors are rational and, the second, that actors' preferences are a given and exogenously determined. Behavioral economics-followed by behavioral law and economics-has questioned the first assumption. This article challenges the second one, arguing that in many instances, social welfare should be enhanced not by maximizing satisfaction of existing preferences but by changing the preferences themselves. The article identifies seven categories of cases where the traditional objections to intentional preferences change by the state and the law lose force and argues that in these cases, such a change warrants serious consideration. The article then proposes four different modes of intervention in people's preferences, varying in intensity, on the one hand, and the identity of their addressees, on the other, and explains the relative advantages and disadvantages of each form of intervention.
\end{abstract}

\footnotetext{
* Alain Poher Professor of Law at Tel Aviv University, Fischel-Neil Distinguished Visiting Professor of Law at the University of Chicago Law School, Visiting Professor of Law at Stanford Law School (Fall 2016) and Visiting Professor of Law at Berkeley Law School (Spring 2017). For their very helpful comments, I thank Ronen Avraham, Oren Bar-Gill, Yitzhak Benbaji, Hanoch Dagan, Yuval Feldman, Talia Fisher, Haim Ganz, Jacob Goldin, Sharon Hannes, David Heyd, Amir Khoury, Roy Kreitner, Tami Kricheli-Katz, Shai Lavi, Daphna LewinsohnZamir, Nira Liberman, Amir Licht, Haggai Porat, Eric Posner, Ariel Rubinstein, Uzi Segal, and the participants in workshops at the Interdisciplinary Center in Herzliya and the Tel Aviv University Faculty of Law. My thanks also to Daniel Kopilov and Dana Zuk for their excellent research assistance.
} 


\section{TABLE OF CONTENTS}

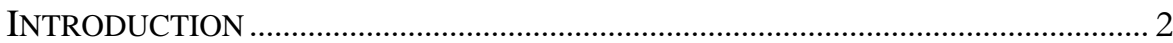

I. PREFERENCES AND OBJECTIONS TO INTENTIONAL STATE INTERVENTION 6

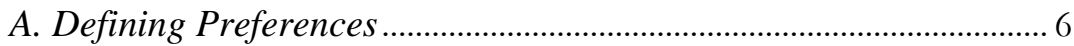

B. Against Intentional State Intervention ................................................. 8

II. WHEN OBJECTIONS TO STATE INTERVENTION LOSE FoRCE ........................ 14

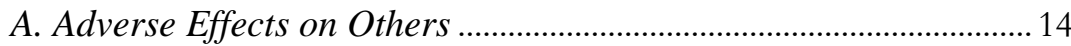

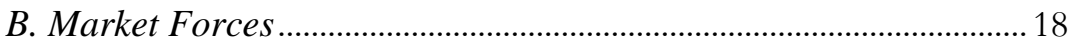

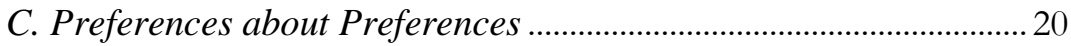

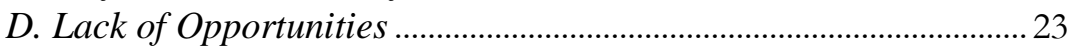

E. Lack of Information and Cognitive Limitations ................................. 25

F. The Collective Action Problem .............................................................26

G. Existing versus Future Preferences ...................................................29

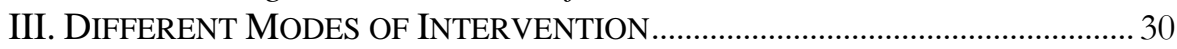

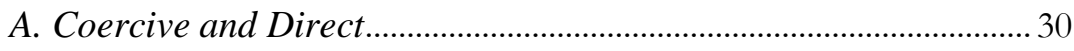

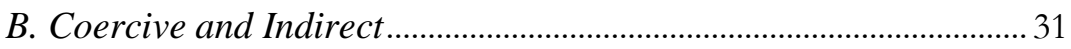

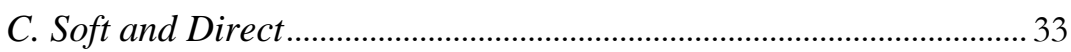

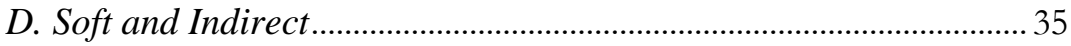

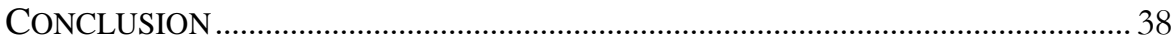

\section{INTRODUCTION}

Standard economic models make two basic assumptions: the first, that actors are rational and, the second, that actors' preferences are a given and exogenously determined. ${ }^{1}$ Behavioral economicsfollowed by behavioral law and economics-questioned the rationality assumption, with scholars in the field showing time and again that actors are often irrational in predictable ways. ${ }^{2}$ Today,

\footnotetext{
${ }^{1}$ See Gary S. BeCKer, The ECONOMIC APPROACH to Human BeHAVIOR 5 (1976) (presenting the fundamental economic assumption of stable preferences); George J. Stigler \& Gary S. Becker, De Gustibus Non Est Disputandum, 67 AM. ECON. REV. 76, 76 (1977) ("Tastes are the unchallengeable axioms of a man's behavior: he may properly (usefully) be criticized for inefficiency in satisfying his desires, but the desires themselves are data. Deplorable tastes-say, for arson-may be countered by coercive and punitive action, but these deplorable tastes, at least when held by an adult, are not capable of being changed by persuasion."); Matthew Rabin, Psychology and Economics, 36 J. ECON. LITERATURE 11, 11 (1998) ("Economics has conventionally assumed that each individual has stable and coherent preferences, and that she rationally maximizes those preferences.").

${ }^{2}$ See Christine Jolls, Cass R. Sunstein \& Richard Thaler, A Behavioral Approach to Law and Economics, 50 STAN. L. REV. 1471 (1998) (presenting behavioral
} 
behavioral economics is justifiably considered an important subfield of economics.

This article challenges the second assumption of the economic (and law and economics) models. It argues that in many instances, social welfare should be enhanced not by maximizing the satisfaction of existing preferences but by changing the preferences themselves.

To illustrate, imagine that in State $X$, people have strong preferences for sweet (and, let's assume, unhealthy) food. ${ }^{3}$ If preferences are taken as a given, the state should aim to maximize the satisfaction of the sum of all of its constituents' preferences, including for sweet food. Alternatively, the state could aim to change people's preferences for sweet food and, once that has been accomplished, maximize the satisfaction of all existing preferences, including the newly acquired ones. It is possible that most or even all individuals would thus be better off in terms of satisfying their preferences. First, those people with a preference for sweet food would now be healthier and happier than they were before the change to their preferences. Second, perhaps some social resources (such as the costs of manufacturing sweet food products) would be saved and directed instead to satisfying other preferences of the former sweet-food lovers or the preferences of other people.

So should the state consider changing its constituents' preferences as a social-welfare enhancing measure? Is it even appropriate for the state and the law to intervene in peoples' preferences to try to change them? Many preferences-such as those relating to sexual orientation - are rightly considered by many to be either unchangeable or such that the state should not intervene in. Other preferences are considered to merit being changed by the state or by others. For example, parents often try to change their children's

economics studies that challenge the rational actor assumption and discussing their implications for the economic analysis of law). For examples of notable contributions in the field of behavioral economics that have called into question the rationality assumption, see Daniel Kahneman \& Amos Tversky, Prospect Theory: An Analysis of Decision under Risk, 47 ECONOMETRICA 263 (1979) (explaining how economic decision-making under uncertainty diverges from neo-classical theory, which is predicated on the notion of rational choice); Amos Tversky \& Daniel Kahneman, The Framing of Decisions and the Psychology of Choice, 211 SCIENCE 453 (1981) (showing that preferences shift in predictable ways when the same problem is framed in different ways); Daniel Kahneman, Jack Knetch \& Richard Thaler, Anomalies: The Endowment Effect, Loss Aversion and Status Quo Bias, 5 J. ECON. PERSPECTIVES 193 (1991) (showing that people often demand more to give up an object than they would be willing to pay to acquire it).

3 Richard H. Thaler \& Cass R. Sunstein, Nudge 1-2 (2009) (showing that small changes in the food setting in school cafeterias can increase the consumption of healthy food). 
preferences, as teachers try to shape their pupils' preferences. The state attempts to change value preferences by, for example, educating its citizens to be loyal to the state or to preserve the environment. Market forces transform people's preferences on a daily basis; Facebook, smartphones, and personal computers are just a few of the abundant examples of how the market can radically change people's preferences. $^{4}$

While the market, the state and sometimes the law commonly shape people's preferences, intentional and, in particular, coercive intervention in those preferences by the state and the law is generally considered to be illegitimate and even dangerous (with a few exceptions, such as soft education for commonly accepted values). Why is this so? Suppose that the state's goal is to change people's preferences in order to maximize social welfare, thereby making every individual better off. Would such a goal be objectionable? ${ }^{5}$ Would changing people's preferences for unhealthy food be a legitimate goal for the state to pursue if we assume that all consumers will be better off once the change takes place? Alternatively, suppose (even though there is no good reason to assume this) that social welfare would be enhanced were all people to have heterosexual preferences. Very few would argue that the state should intervene to change people's sexual orientation even if no individual would be worse off. The question that arises, then, is what underlies the opposition to the state's changing people's preferences?

A number of objections can be raised against intentional state intervention in people's preferences. First, allowing the state to change preferences could infringe on individual freedom: instead of letting individuals shape their preferences by themselves, the state would be doing this for them. ${ }^{6}$ Second, the state might abuse its power and change people's preferences not to promote their own welfare but to promote the rulers' interests. ${ }^{7}$ Third, allowing the state to change people's preferences would entail that it take a stand on

\footnotetext{
4 The widespread use of smartphones, for example, could be explained by the network effect: the more people who have smartphones, the more beneficial it is to use them. Yet clearly, there is more to the choice of many to own a smartphone; it derives also from their (relatively new) preference to be in constant contact with others.

${ }^{5}$ It would then be a Pareto, rather than Kaldor-Hicks, improvement. $C f$. Robert Cooter, Models of Morality in Law and Economics: Self-Control and SelfImprovement for the "Bad Man" of Holmes, 78 B.U. L. REV. 903, 922-25 (1998) (explaining that Pareto self-improvement refers to a change in preferences that would be preferred by both the actor's original and final (after-change) self).

${ }^{6}$ Infra Section I.B.

${ }^{7}$ Infra Section I.B.
} 
which preferences are the "good" ones deserving of promotion and which are the "bad" ones that should be repressed. Allowing the state such a role would conflict with liberal political theory, which calls for a neutral role for the state in promoting the social good. ${ }^{8}$ Fourth and lastly, any effort to change people's preferences would necessarily entail uncertainty: it is typically unclear as to whether any given change would increase or decrease social welfare. ${ }^{9}$

Insofar as they are intended to be general and broad in scope, these four objections to state intervention in preferences lose force once we acknowledge that in actuality, the state and the law influence our preferences in most aspects of our lives and, more importantly, that this is entirely unavoidable. Rights and duties, the allocation of private and public resources, and the social structure in which we live shape our preferences from the moment we are born. This seems to occur unintentionally, implicitly, and coincidentally, but it nevertheless occurs universally. So if this is the case, why should the intervention not be purposive, explicit, and with appropriate awareness, thereby making transparent a process that is currently obfuscated and surreptitious? ${ }^{10}$ Transparency would make the process of preferences change by the state subject to public (as well as judicial) scrutiny and consistent with the basic tenets of liberal democracy. ${ }^{11}$

I begin in Part I by laying out what "preferences" will refer to in this article. I distinguish between internal and external preferences and among preferences that are tastes, preferences tied to personal characteristics or tendencies, preferences relating to other people, preferences relating to ways of life, and preferences motivated by

\footnotetext{
${ }^{8}$ Infra Section I.B.

${ }^{9}$ Infra Section I.B.

${ }^{10}$ At the same time, it could be argued that coincidental changes of preferences by the state are inevitable and their presence does not justify intentional changes. See JOHN RAWLS, POLITICAL LIBERALISM 66-71 (1993) (arguing that publicity is an aspect of fairness); Cass R. Sunstein, Legal Interference with Private Preferences, 53 U. CHI. L. REV. 1129, 1154 (1986) (arguing that some preferences are the product of past power relations and therefore a transparent preferences change policy can shape these distorted preferences in accordance with liberal principles).

11 Cass Sunstein asserted, in an article he published in 1986, that existing objections to changing private preferences through the law notwithstanding, this should be done, for the most part, in cases where some type of collective action problem is preventing a desirable change. Sunstein, supra note 11 . Here, I add several categories of cases to those Sunstein discussed, as well as offering more general guidelines for state intervention. In particular, I suggest various ways of changing people's preferences, including "nudging," a technique proposed by Thaler \& Sunstein for changing people's behavior but not preferences, THALER \& SUNSTEIN, supra note 3, and show how they can be applied in different contexts.
} 
personal values. The discussion then elaborates on possible objections to the state's changing preferences. This sets the stage for the article's main claim, put forth in Part II, namely, that at least in some circumstances, these objections lose their force. Part III proposes four possible ways the state can intervene in preferences and the Conclusion summarizes the arguments made in the article. ${ }^{12}$

\section{PREFERENCES AND OBJeCtions to InTENTIONAL StATE AND LAW}

\section{INTERVENTION}

This part of the article lays the groundwork for identifying cases in which at least certain modes of intentional state and law intervention in people's preferences can be expected to trigger fewer objections than in other cases. Section A defines "preferences" for the purposes of this article, explaining that the term is used in a far broader sense here than how it is generally used by economists. Section B then elaborates on the central possible grounds for objecting to the state changing preferences.

\section{A. Defining Preferences}

To define preferences, I will first exclude what can be termed external, as opposed to internal, preferences. External preferences refer to people's desires to give precedence to one act or state of the world over another act or state of the world when this is motivated by either threat of sanction or promise of benefit from others. A person who likes smoking might have an external preference not to smoke because he fears legal sanctions or expects condemnation from his friends and family. A person might have an external preference not to smoke also because the price of cigarettes has gone up or he's been offered a monetary reward if he stops smoking. Such preferences are beyond the scope of this article, which focuses on internal preferences, namely, those preferences that are generated by internal, rather than external, forces. ${ }^{13}$ For example, the person who

\footnotetext{
${ }^{12}$ A full-fledged theory of justified preferences change by the state should take into account also the psychological and physiological processes of such a change and not only the normative impediments. See Amir N. Licht, Law for the Common Man: An Individual-Level Theory of Values, Expanded Rationality, and the Law, 74 LAW \& CONTEMP. PROBS. 175, 188 (2011) (presenting the psychological aspects of preferences change).

13 Some take "preferences" to refer only to internal preferences, while others see it as encompassing both internal and external preferences. Daphna LewinsohnZamir, The Importance of Being Earnest: Two Notions of Internalization, $65 \mathrm{U}$. TORONTO L.J. 37, 49-51 (2005) (explaining that whereas internal preferences are attributed to intrinsic motivations, external preferences are attributed to external
} 
likes smoking has an internal preference to do so even though his external preference is to stop smoking.

Internal preferences (which I'll hereinafter refer to simply as "preferences") can be both strictly and broadly defined. Strictly defined, they are the desires people have, when motivated by internal forces, to favor one act or state of the world over another. Broadly defined, preferences include also the values and tastes people have that affect and shape their strictly defined preferences. In this article, preferences will be broadly, rather than strictly, construed.

What preferences do people have? One type of preferences is tastes, for example, a preference for sweet food. Someone with a taste for sweet food will be driven to prefer (strictly speaking) one type of food (sweet) over another type (non-sweet).

A second type of preferences relates to personal characteristics or tendencies, like sexual preferences, for example. A man's homosexual tendencies result in his preference (strictly speaking) of intimate relations with a man rather than with a woman.

A third type of preferences relates to attitudes towards other people, such as racist preferences. A person with racist preferences prefers (strictly speaking) the company of people from one or more races to the company of people from another race or other races.

A fourth type of preferences is connected to ways of life, for example, the preference to live as part of a family unit or to be connected to many (or few) people. A person with a preference to live as part of a family unit prefers (strictly speaking) getting married (or living with a common-law partner) to remaining single.

Fifth and lastly, there are preferences that are tied to values that people hold, such as solidarity, individualism, or materialism. ${ }^{14} \mathrm{~A}$ person with a preference for solidarity, for example, might prefer (strictly speaking) to support (morally or materially) certain groups or communities with whom she identifies over not supporting those groups or communities.

It becomes clear, then, that preferences often involve views and

incentives).

14 The term "preference" could relate to almost everything, including matters that are in no way connected to the well-being of the preference holder (say, an American citizen with a preference that the Israeli prime minister be goodlooking). Therefore, some argue, the only preferences that should count are those that relate to the preference holder's life or well-being. See, e.g., DEREK PARFIT, REASONS AND PERSONS 484 (1987). But see RONALD DWORKIN, TAKING RIGHTS SERIOUSLY 275-76 (1980). Dworkin distinguishes between external preferences, which relate to other people, and internal preferences, which relate to the preference holder. According to Dworkin, only the latter should count. See also Amartya SEN, Commodities AND CAPABILITIES 14-15 (1999), who maintains that a person's private preferences derive from his conception of what he can attain. 
moral stances that might be based on accurate or false evidence or beliefs. Thus, a person might prefer sweet to non-sweet food based on the mistaken perception that the former is healthier than the latter; he might prefer to avoid social interaction with gay people, believing homosexuality to be immoral; he might have racist preferences regarding ethnic minorities, holding them to be inferior; or he might prefer not to smoke or to eat excessively even though he enjoys both, simply because he believes smoking and overeating to be unhealthy. Even addictions are preferences under this article's terminology, regardless of whether the addict prefers, in a deep sense, not to be addicted. ${ }^{15}$

Certain distinctions emerge amongst the examples presented thus far: between authentic and acquired preferences; between preferences that are central to an individual's personality and preferences that are peripheral to personality; and between preferences with a moral or value dimension and preferences that lack such a dimension. While these distinctions are important in any discussion of preferences and the various options for changing them, all of these preferences are related to as simply "preferences" in the discussion in this article.

\section{B. Against Intentional State Intervention}

Why should intentional state and law intervention in people's preferences not be allowed as an intermediate measure towards maximizing social welfare? On what grounds could this be opposed?

One argument against such intervention in preferences concerns personal freedom: regardless of whether changing a person's preferences enhances her welfare, her freedom would be infringed on. Per this argument, freedom precedes welfare, at least insofar as the basic freedom to shape one's preferences is concerned. Interfering with this freedom, the argument goes, is analogous to cloning human beings as it alters their self and identity.

This argument rests on the premise that a person should have the freedom to choose her preferences just as she has the freedom to

\footnotetext{
15 There are philosophers who would consider only rational preferences based on a deliberative process in which a person chooses her own rational ends to be internal preferences. This is a Kantian conception, under which only rational behavior, which is directed at choosing the right end, is authentic and not subject to external motivations. IMMANUEL KANT, GROUNDWORK OF THE METAPHYSIC OF MORALS (1785) (H.J. Paton trans., Harper Torchbooks 1964). By this conception, a preference for sweet food is an external rather than internal preference (of the body and not of the mind). In contrast, Hume argued that as a purely empirical matter, we can't talk about any preferences being authentic or essential to a person. DAVID Hume, A Treatise of Human Nature 293-96 (1740) (Dover Publications 2003).
} 
choose her way of life, even when those choices impair her welfare. ${ }^{16}$ Thus, a person's preference to smoke should be respected regardless of the proven risks that preference subjects her to, and the state should not intervene in her choice.

A different angle to this argument is that interfering in people's preferences infantilizes them. ${ }^{17}$ Rather than being instigated by mental evolution and growth or a simple learning process, the changes to people's preferences will be the outcome of the state's paternalistic intervention. Commonly raised regarding paternalistic intervention in behavioral choices, ${ }^{18}$ this objection is no less validif not more so-when preferences are at stake. In the case of smoking, for instance, there is much merit to smokers' undergoing a process of realizing that their smoking preferences are detrimental to their wellbeing and changing them accordingly. When the state assumes responsibility for detecting and changing such preferences, individuals may be led into a state of atrophy. ${ }^{19}$

A second argument against preferences changing by the state centers on the abuse of power concern. According to this argument, since political power is always coercive and backed by the state's ability to impose sanctions, ${ }^{20}$ the state is likely to exploit its power to

\footnotetext{
${ }^{16}$ See Amartya Sen, Markets and Freedoms: Achievements and Limitations of the Market Mechanism in Promoting Individual Freedoms, 45 OXFORD ECON. PAPERS 519, 524 (1993). Sen takes the "process aspect of freedom" to include decisional autonomy and immunity from interference. The former, he stresses, "is concerned with the operative role that a person has in the process of choice ... . [T] he crucial issue here is self-decision, e.g., whether the choices are being made by the person herself-not (on her behalf) by other individuals or institutions." Id.

${ }^{17}$ Cf. Joshua D. Wright \& Douglas H. Ginsburg, Behavioral Law and Economics: Its Origins, Fatal Flaws, and Implications for Liberty, 106 Nw. U. L. REV. 1033, 1070-71 (2012) (arguing that paternalistic intervention in individual decisionmaking "tends to infantilize the public").

18 See, e.g., Cass R. Sunstein, Choosing Not to Choose, 64 DUKE L.J. 1, 30-36 (2014) (debating the merits of learning as an advantage for active choosing over paternalistic approaches); CASS R. SUNSTEIN, WHY NUDGE? 94-96 (2014) (presenting the objection to soft paternalism on the grounds of possible public infantilization). Paternalistic policies are also seen as diminishing the expressive function of law. Although norms and behaviors can be shaped simply through the authoritative statements of the law, a paternalistic approach prefers that the law operate in the background, unbeknownst to its targets. See Yuval Feldman \& Orly Lobel, Behavioural Trade-Offs: Beyond the Land of Nudges Spans the World of Law and Psychology, in Nudge AND THE LAW: A EUROPEAN PERSPECTIVE 301, 314-17 (Alberto Alemanno \& Anne-Lise Sibony eds., 2015).

${ }^{19}$ Cf. John STUART MiLl, ON LiBERTY 37 (David Bromwich \& George Kateb eds., 2003) ("The mental and moral, like the muscular powers, are improved only by being used.").

${ }^{20}$ RAWLS, supra note 11, at 136 (discussing the features of political power within
} 
change people's preferences in a way that serves its own interests rather than those of the individuals. ${ }^{21}$ Such changes should, therefore, be prohibited or, at the very least, strictly limited. This argument is a derivative of the basic idea that the ruler's authority should always be limited given the danger that it will try to capture more than its fair share of the "good." 22 This concern also arises with respect to paternalistic intervention by the state in general, ${ }^{23}$ and it has even greater force regarding preferences: intervention in preferences is analogous to subordinating citizens to the will of the monarch through brainwashing and similar techniques.

In abusing its power, the state could be internally motivated by the interests and views of the policymaker herself. Such would be the case, for example, when a conservative administration promotes prolife preferences or a liberal administration promotes pro-choice preferences regardless of how such a change could impact social welfare. The state's motivation could also, however, be externally driven, the product of the lobbying of a non-governmental actor. ${ }^{24}$ This would be the case when a fast-food corporation uses its political clout to promote a change in people's taste preferences, thereby benefiting itself at the expense of the public good. What is troublesome, in other words, is that efforts to change preferences would not be unilateral, with the state the sole initiator of the change, but rather bilateral or multilateral, with interest groups seeking to change the social planner's preferences, ${ }^{25}$ who, in turn, would

constitutional regimes).

21 There are any number of alternatives for intervening in people's preferences. Some would be more objectionable than others because of the risk of abuse of the state's power. See infra Part III. Thaler \& Sunstein, supra note 3, famously advocated intervening in people's behavior (not preferences!) through "nudging." This suggestion has drawn some criticism, to which Sunstein has attempted to respond in SunsteIN, Why Nudge?, supra note 18, at 12. See also Ayala Arad \& Ariel Rubinstein, The People's Perspective on Libertarian-Paternalistic Policies (July 2015) (unpublished manuscript), available at www.tau.ac.il/ aradayal/LP.pdf (showing that individuals might counter-react to a nudge from the state by doing the opposite of what is expected of them).

22 John Finnis, Is Natural Law Theory Compatible with Limited Government?, in NATURAL LAW, LIBERALISM AND MORALITY 1, 2 (1996) (discussing the justification for limited government).

${ }^{23}$ MILL, supra note 19, at 143-44 (arguing that intervention in a person's life is justified only when she inflicts harm on others).

${ }^{24}$ A similar concern has been raised as an objection to soft paternalism. The State Is Looking After You, ECONOMIST (Apr 6th 2006), http://www.economist.com/node/6772346.

25 See Mingli Zheng, Lobbying for Wealth Redistribution by Changing the Social Planner's Preferences, 26 J. THEORETICAL POL. 79, 79-92 (2013) (modelling the effects of interest group lobbying on a framework for changing the social planner's 
implement policies that impose those preferences on the public.

In the common abuse-of-power scenario, there would be a "slippery slope," 26 where the state gradually eases its restraint and intensifies its intervention for the sole purpose of furthering its own objectives and interests. There are two ways in which this could happen: through an intensification of means, whereby the state unnecessarily and disproportionately shifts from soft to harsh intervention or, alternatively, resorts to progressively-less-visible means of persuasion; ${ }^{27}$ or through an intensification of scope, whereby the state begins to take avenues of intervention initially deemed excessively pervasive or offensive, such as intervention in sexual preferences.

The concerns regarding state overreach are exacerbated by the lack of transparency that intervention policies tend to suffer from. Coercive forms of intervention ${ }^{28}$ can be expected to be conducted in public view; this would be the case, for instance, with the prohibition of an activity that is intended to impact private preferences to engage in that activity. However, subtler and softer forms of intervention ${ }^{29}$ might not be publicly visible, as their effectivity hinges on a certain degree of ambiguity. Sunlight has been called the best of disinfectants, ${ }^{30}$ so it is clear why already-suspect intervention intensifies concerns when performed behind the veil of opacity. Even a state that severely infringes on civil rights and acts against the will of its people cannot be held accountable if its actions aren't subject to proper public scrutiny. ${ }^{31}$

A third argument, which is related to the second one, focuses on

preferences).

26 See THALER \& SUNSTEIN, supra note 3, at 236-38, who debate a similar slippery-slope objection in the context of state intervention in people's behavior. For an example of such an objection, see Douglas Glen Whitman \& Mario J. Rizzo, Paternalistic Slopes, 2 N.Y.U. J.L. \& LIBERTY 411 (2007), reviewing and analyzing the relationship between the slippery-slope argument and paternalist policymaking.

${ }^{27}$ See Riccardo Rebonato, A Critical Assessment of Libertarian Paternalism, $37 \mathrm{~J}$. CONSUMER POL'Y 357, 368-69 (2014) (applying the slippery-slope argument to the possibility of modes of influence becoming less overt).

${ }^{28}$ Infra Sections III.A-B.

${ }^{29}$ Infra Sections III.C-D.

${ }^{30}$ Louis D. BRANDEIS, What Publicity Can Do, in OTHER PeOPle's MoneY AND HOW THE BANKERS USE IT 62, 62 (1914) (Harper Torchbooks 1967).

${ }^{31}$ For a discussion of publicity concerns in the context of soft paternalism, see SunsteIn, Why Nudge, supra note 18, at 144-51. See also Edward L. Glaeser, Paternalism and Psychology, 73 U. CHI. L. REV. 133, 151-52 (2006) (objecting to soft paternalism due to the greater difficulty of monitoring it as compared to hard paternalism). 
the role of the state. Per this argument, the state should take a neutral stance on people's preferences. ${ }^{32}$ The main justification for this is that people have many different and, at times, conflicting conceptions of what constitutes the "good," and the state's traditional role of promoting the good cannot encompass all of those conceptions. ${ }^{33}$ Accordingly, under liberal political theory, the state's role should be limited to protecting and enforcing the most fundamental civil liberties and political rights, producing public goods, and enabling all individuals to pursue their own conceptions of the good. ${ }^{34}$ It is the state's duty, therefore, to set the boundaries within which individuals live their lives and guarantee the conditions necessary for them to fulfill their hopes and ambitions as they see fit. $^{35}$

Given this, the state should not determine which preferences are the "right" ones for individuals and intervene to promote them, even if this would not be an abuse of its power. For example, a particular group within the state might impose conservative dress codes on its members as part of its religious ideology, while other groups might strongly oppose this norm as oppressive. Under the logic of the role of the state argument, the state should not interfere with the former group's preferences or actions even if positive utility effects can be expected from this intervention, for it would be akin to depriving religious freedom and preferring a progressive notion of the "good" over a conservative one.

The fourth and last argument relates to uncertainty: it is often unclear whether the state's intervention in preferences would actually increase and not decrease social welfare. This argument tends to be supported by both economists and legal economists. ${ }^{36}$ In constructing

\footnotetext{
32 RAWLS, supra note 11, at 133-211 (explaining that the state ought not to privilege one conception of good over another).

${ }^{33}$ RAWLS, supra note 11 , at 134-36, 191-92.

${ }^{34}$ JOHN RAWLS, THE LAW OF PEOPLES 172-73 (1st ed. 1921) (1999) (discussing the basic liberties the state should protect).

35 Allen E. Buchanan, Assessing the Communitarian Critique of Liberalism, 99 ETHICS 852, 854 (1989) (defining the proper role of the state under liberal political theory); Richard B. Stewart, Regulation in a Liberal State: The Role of NonCommodity Values, 92 YALE L.J. 1537, 1539 (1983). But see Joseph Raz, Liberalism, Autonomy, and the Politics of Neutral Concern, 7 MIDWEST STUD. PHIL. 89, 116 (1982), who differentiates between taking coercive measures against morally unacceptable activities (which he rejects) and fostering positive ideas while suppressing the conditions that make negative ideas appealing (which he supports).

${ }^{36}$ LOUIS KAPLOW \& STEVEN SHAVELL, FAIRNESS VERSUS WELFARE 413-31 (2002) (suggesting that changing undesirable preferences might be welfare-enhancing and discussing the problems with identifying such preferences).
} 
their models, economists commonly assume preferences to be a given and exogenous (i.e., not shaped through state intervention). While primarily motivated by a desire to simplify a rather complicated model, this assumption rests on the premise that it is too difficult to predict how intervention would change individuals' preferences. The resulting conclusion is that the state should not intervene in preferences, since intervention cannot be justified if we cannot predict the outcome.

But there is another dimension to the uncertainty argument: if the state's goal is to maximize the satisfaction of existing preferences, there is no need to measure the utility people derive from their preferences. It is sufficient that the preferences are satisfied, since more satisfaction means more utility, or welfare, and that is all that matters. Yet this is not so when the state's goal is to change preferences in order to increase social welfare: here the state should measure the utilities of existing preferences, compare them with the utilities of the potential preferences, and decide accordingly whether the change is worth pursuing. Measuring utilities and conducting the necessary comparisons could be a formidable task for the state. ${ }^{37}$ Therefore, even if we could resolve the uncertainty about the change that the state's intervention in preferences would bring about, the uncertainty as to whether that change would be good or bad would still remain. ${ }^{38}$

The four objections to intentional preferences change by the state discussed above are not without merit. They can explain the resistance of many economists and moral philosophers to the idea that changing preferences can sometimes be a desirable intermediate stage on the way to maximizing social welfare. Part II below now proceeds to identify categories of cases in which some of these objections collapse or at least are less compelling than usual.

${ }^{37}$ Cf. Glaeser, supra note 31, at 151 (arguing against soft paternalism on grounds of expected errors).

${ }^{38} \mathrm{Cf}$. Jeremy Bentham, A Comment on the Commentaries and a Fragment on Government, in THE COLLECTED WORKS OF JEREMY BENTHAM 393 (J.H. Burns \& H.L.A. Hart eds., 1977). Bentham argues that a person's happiness is valued according to her balance of pleasure and pain. Therefore, the state bears a duty to increase the amount of pleasure for the greatest number of people. Mill, who distinguished between higher and lower pleasures, argued that higher pleasures are generally more intellectual than physical (for example, the pleasure in practicing philosophy versus the pleasure derived from tasty food). JOHN STUART MILL, UTILITARIANISM, at ch. 2 (1861) (Oskar Piest ed., Bobbs-Merrill 1957). 


\section{WHEN OBJECTIONS TO STATE INTERVENTION LOSE FORCE}

There are various ways in which preferences are first acquired and then subsequently altered. Some preferences can be changed by the preference holder himself, with or without the assistance of others; other preferences are difficult to change without state intervention. Some preferences have almost no external effects on third parties, while others do. Some preferences do not truly, in a deep sense, constitute preferences, whereas others are genuine preferences. Finally, some preferences relate to people's identity and personality, and others are peripheral. These variations in preferences are relevant to whether intentional state and law intervention to change them is desirable. This part will respond to this question by identifying cases, or conditions, in which intervention might be justified.

\section{A. Adverse Effects on Others}

A common justification for the state and the law to intervene in people's behavior is when it adversely affects other people's interests. This is the rationale for tort law, for example. ${ }^{39}$ Likewise, in contract law, the imposition of negative externalities on third parties is a common justification for intervening in contracts: a contract will be found unenforceable on public policy grounds when it can negatively affect third parties or society at large. ${ }^{40}$ In addition, a common justification for regulations is the need to restrain activities that put third parties at risk. ${ }^{41}$

The possibility of preferences' creating negative externalities for third parties undermines the objection to state intervention. Clearly, the risk of negative externalities per se would not necessarily be a sufficient condition for intervening in the risk-creator's preferences, just as this would not necessarily justify intervening in people's behavior. Nevertheless, negative externalities are an important factor when considering state intervention in both conduct and preferences.

There are two ways in which preferences might produce negative externalities. First, some preferences could be transformed into conduct that inflicts harm on third parties. Second, people with

\footnotetext{
${ }^{39}$ DAN B. DOBBS, THE LAW OF TORTS 12 (2000).

${ }^{40}$ RESTATEMENT (SECOND) OF CONTRACTS $§ § 178-99$ (1981).

${ }^{41}$ See generally A.C. Pigou, The ECONOMICS of Welfare (4th ed. 1932) (proposing that externalities be remedied through regulation in the form of taxes); Michael E. Levine \& Jennifer L. Forrence, Regulatory Capture, Public Interest, and the Public Agenda: Toward a Synthesis, 6 J.L. ECON. \& ORG. 167, 168 (1990) (describing the public interest theory of regulation, which views government intervention as necessary to protect the public from the effects of externalities).
} 
certain undesirable preferences might "infect" others with those preferences. In some cases, these two modes of externalization converge: some preferences are both injurious and infectious. It is in this latter type of cases that the objection to state and law intervention becomes especially weak.

Arguably, the state and the law could wait to contend with the externalization risk until it actually materializes. But as I will demonstrate, the earlier the intervention, the more likely it is to be both more effective and, ultimately, less burdensome for the preference holder. To illustrate, consider racist preferences: Imagine that the law could alter these preferences in a positive direction. Should it intervene to that effect? One possible response is that the law, and the state, should ignore racist preferences so long as they do not result in injury to third parties. Indeed, various laws prohibiting racist incitement condition legal intervention on injurious effects on third parties or at least an imminent risk of such injury. ${ }^{42}$

Arguably, however, this is not enough. To begin with, racist preferences could result in injurious conduct that is difficult or even impossible to detect: it is completely implausible that anyone who acts in a racially discriminatory way towards others will be brought to trial. Second and more importantly, racist preferences are infectious and epidemic; ${ }^{43}$ infection is bad on its own but much worse when it exacerbates the risk of injury to third parties. Thus, racist parents are likely to infect their children with their racist preferences, as are racist teachers likely to infect their pupils. Racist leaders might infect their supporters with their preferences, as might cultural icons. In fact, anyone with racist preferences is likely to infect others. So while it is possible to refrain from intervention until actual injury (or "infection") occurs, prior intervention to change racist preferences-particularly when held by people who tend to wield influence over others-will often be much more effective than at the later stage. How such intervention can be accomplished is a different question altogether and will be discussed in Part III.

State intervention in people's preferences to prevent injury to

42 See Sunstein, supra note 11, at 1147 (arguing for the injurious effects of discriminatory preferences even when the injured party seems content with the status quo).

${ }^{43}$ See, e.g., Bobbie Harro, The Cycle of Socialization, in READINGS FOR DIVERSITY AND Social Justice 15, 15-18 (Maurianne Adams et al. eds., 2000) (discussing how personal identities and views, particularly oppressive and prejudiced opinions, are shaped by one's parents and the institutions one attends); Jeff Greenberg \& Tom Pyszczynski, The Effect of an Overheard Ethnic Slur on Evaluations of the Target: How to Spread a Social Disease, 21 J. EXPERIMENTAL SOC. PSYCHOL. 61 (1985) (showing that ethnic slurs cue prejudiced behavior in those who are exposed to them). 
third parties is not only essential for replacing existing "undesirable" preferences with "desirable" ones but also for creating completely new preferences. Take the example of the preference for order. Sometimes this preference can do more harm than good, especially if it becomes obsessive or impairs discretion. ${ }^{44}$ Yet sometimes this preference is crucial. In the military or in the framework of risky activities, preference for order could save lives. It is no coincidence that armies consistently strive to instill this preference in their soldiers. In this context, too, it could be argued that armies should focus on the injurious effects of disorder rather than on fostering a preference for order. However, the risk that a lack of preference for order (or a preference for disorder) will spread and infect others and result in irreparable harms justifies creating a preference for order amongst soldiers (up to a certain point, of course) even prior to the occurrence of injury to third parties. The early stages of this process could be considered a change to an external preference, ${ }^{45}$ since soldiers prefer order because of the threat of punishment from their superiors. But its ultimate goal is a change of an internal preference, through the development of personal characteristics independent of external incentives or threats.

Thus far, we have seen that intervention in preferences by the state and the law would be more effective at preventing negative externalities to third parties if it were carried out prior to the actual infliction of harm. But no less significant is the fact that early intervention can be less burdensome or less costly for the preference holder. To understand this, assume that the state seeks to prevent smoking in public places so as to protect third parties from passive smoking. One way to accomplish this would be to prohibit smoking in public places and impose sanctions on violators. Another way, however, would be to change smokers' preferences so that they would cease to prefer to smoke. ${ }^{46}$ Not only would the latter solution

\footnotetext{
44 See, e.g., Emel Arslan, An Investigation of Social Skills in Children with Different Perfectionism Levels, 6 EDUC. RES. \& REV. 279, 281 (2011) (arguing that perfectionist individuals, who tend to be excessively organized, suffer from distressed and unsatisfying lives); Jerald Kay \& Deborah Y. Liggan, Diagnosis and Treatment of Personality Disorders, 4 PSYCHIATRY BOARD REV. MANUAL 1, 7 (2000) ("Persons with obsessive-compulsive personality disorder are excessively organized, neat and conscientious. These traits impair the individual's functioning because attention to detail is so excessive or time-consuming that the point of the activity is lost.").

${ }^{45}$ Supra Section II.A.

46 See Bryan Norton et al., The Evolution of Preferences: Why "Sovereign" Preferences May Not Lead to Sustainable Policies and What to Do About It, 24 ECOLOGY ECON. 193, 205-06 (1998) (debating the concept of discouraging preferences for smoking to advance the social goal of ensuring a healthy
} 
be more effective in attaining the state's goal but it could also reduce or even eliminate the costs to smokers of quitting smoking. ${ }^{47}$ For any smoker who would retain a weak preference for smoking, light sanctions would suffice to deter him from satisfying that preference in public places. ${ }^{48}$

Exemplifying well the advantages of early intervention is the context of environmental preservation. ${ }^{49}$ Here, changing preferences might be not only the more effective way to achieve this goal but also less costly for the individuals required to act to preserve the environment. Sex offenders are another, albeit very different, example. In some countries, sex offenders such as pedophiles are offered the option of medical treatment that will alter (or suppress) their sexual preferences instead of serving a long jail sentence. ${ }^{50}$ While coercive medical treatment is strongly objected to, this opposition diminishes if the offender agrees to the treatment voluntarily. ${ }^{51}$ But regardless of one's moral stance on medical treatment as an alternative to a jail sentence, it is fairly indisputable that treatment is often the less burdensome option for the offender.

Clearly, however, state intervention in preferences is not justified in all instances in which the relevant preferences could impose negative externalities on others. In addition to the potential infringement on the individual's freedom, the state's intervention could have other negative effects. Many potentially injurious preferences have positive aspects that would be lost were those preferences changed. While a preference of aggressiveness could

population); Christina Rasco, Discouraging Smoking: Interventions for Pediatric Nurse Practitioners, 6 J. Pediatric Health CARE 200 (1992) (outlining methods for discouraging adolescent smoking).

${ }^{47}$ Changing preferences would also suppress smokers' desire to smoke in private places, which would be for their own good. At the same time, some smokers might prefer to retain their preferences to smoke and engage in smoking in private places.

${ }^{48}$ See Levinson-Zamir, supra note 13, at 67 (changing preferences might infringe on autonomy less than interference in behavior).

${ }^{49}$ Cass R. Sunstein, Endogenous Preferences, Environmental Law, 22 J. LEGAL STUD. 217 (1993) (presenting the preferences change effects of environmental regulation).

${ }^{50}$ It could be argued, however, that the medical treatment does not truly change their preferences but only inhibits their satisfaction.

${ }^{51}$ See Karen Harrison, The High-Risk Sex Offender Strategy in England and Wales: Is Chemical Castration an Option?, 46 HOWARD J. 16, 19 (2007) (discussing objections to surgically castrating offenders and noting that this practice is offensive when performed against the offender's will); John McMillan, The Kindest Cut? Surgical Castration, Sex Offenders and Coercive Offers, J. MED. ETHICS 1 (2013) (discussing the validity of sex offenders' consent to undergoing castration and concluding that it should not be viewed as cruel or inhumane treatment when no coercion is involved). 
impose negative externalities on others, it might, at the same time, offer social benefits, for example, for the military, which cannot function without aggressive soldiers. ${ }^{52}$

\section{B. Market Forces}

Market forces shape people's preferences on a daily basis. ${ }^{53}$ Underlying these forces is the desire of merchants to maximize their profits rather than enhance social welfare. In fact, market forces could certainly operate to enhance social welfare. But because of information asymmetries, consumer irrationality, or the inability of consumers to organize to promote their collective interests, ${ }^{54}$ market forces tend to change consumer preferences in a way that serves merchants' rather than consumers' interests. ${ }^{55}$

To understand this, let us return to the smartphone example. For many people, smartphones create a preference to be in continuous social contact. ${ }^{56}$ Merchants have an obvious interest in shaping such a preference: the more people who have these phones, the more other people buy them and related applications and accessories, and the stronger people's preference to be connected. Needless to say, the big winners are inevitably the merchants. Merchants have a similar self-evident interest to foster consumer preferences to over-

52 Of course, in an ideal world, there are no armies and there is no need for soldiers' aggressiveness. Yet it is questionable whether zero aggressiveness is what we want to have even in an ideal world.

53 See generally DAVID GeORge, Preference Pollution: How Markets CREATE THE DESIRES WE DisLIKE (2004) (analyzing how the market influences preferences and how this contributes, if at all, to efficiency).

54 OREN BAR-GIL, SEDUCTION BY CONTRACT: LAW, ECONOMICS, AND PSYCHOLOGY IN CONSUMER MARKETS 17 (2013) (presenting the notion of market failure in consumer markets).

55 See Ronald J. Schindler, The Frankfurt SchoOl CRITIQUE OF CAPITALIST CULTURE 133-34 (1998), explaining the relationship between capitalist ideology and individuals' false consciousness regarding their true needs. According to the Frankfurt School thinkers, capitalism has created false human needs that induce greater consumption.

56 See, e.g., A Nation Addicted to Smartphones, OfCOM (Aug. 4, 2011), http://consumers.ofcom.org.uk/news/a-nation-addicted-to-smartphones (presenting various indicators of smartphone addiction in the UK, such as the finding that a vast majority of users have their phones switched on all the time, even when in bed); Elizabeth Anderson, Teenagers Spend 27 Hours a Week Online: How Internet Use Has Ballooned in the Last Decade, THE TELEGRAPH (May 11, 2015), http://www.telegraph.co.uk/finance/newsbysector/mediatechnologyandtelecoms/di gital-media/11597743/Teenagers-spend-27-hours-a-week-online-how-internet-usehas-ballooned-in-the-last-decade.html ("People are spending twice as much time online compared to 10 years ago, fuelled by increasing use of tablets and smartphones."). 
consume. ${ }^{57}$ As with smartphones, consumers are incapable of organizing to prevent the cultivation of these new and not necessarily desirable preferences, making merchants free to do whatever will advance their interests.

Addiction is particularly illustrative of this phenomenon: merchants and manufacturers strive to make their products addictive for consumers, ${ }^{58}$ with cigarettes, alcohol, and drugs the most obvious examples. As we will see below, ${ }^{59}$ addiction is a sub-category of a broad class of cases in which people have a second-order preference (to avoid drugs, for example) about a first-order preference (to consume drugs). In such instances, state intervention to change firstorder preferences could be justified regardless of whether they were produced by market forces or created in a different way.

A final example comes from the world of modeling. Modeling agencies notoriously demand of their models, especially female ones, to maintain a low weight even if harmful to their health. ${ }^{60}$ The economic motivation behind this is the notion that clothing looks best on thin models. This serves to cultivate in many young girls, who are exposed to these images of thin models, a narrow perception of beauty and a strong preference for thinness, to the point of anorexia in extreme cases. ${ }^{61}$

${ }^{57}$ See Hans Kjellberg, Market Practices and Over-Consumption, 11 ConSUMPTION MKT. \& CULTURE 151, 151-52 (2008), for a review of prominent studies on how marketing activities affect consumption, see B. Wansink \& S.B. Park, At the Movies: How External Cues and Perceived Taste Impact Consumption Volume, 12 FOOD QUALITY \& PREFERENCE 69 (2001) (showing that moviegoers consume more popcorn than usual, regardless of tastiness, when served in a larger container).

${ }^{58}$ For the definition of addiction, see Sunstein, supra note 11, at 1158 .

${ }^{59}$ Infra Section C.

${ }^{60}$ See, e.g., Antonio Preti et al., Eating Disorders Among Professional Fashion Models, 159 PSYCHIATRY RES. 86 (2008) (finding that fashion models report significantly more symptoms of eating disorders and are more commonly underweight than members of a control group composed of girls of the same age and social and cultural background); David M. Garner \& Paul E. Garfinkel, SocioCultural Factors in the Development of Anorexia Nervosa, 10 PsyCHOL. MED. 647 (1980) (finding an overrepresentation of anorexia and excessive dieting concerns among dance and modelling students and hypothesizing this to be the result of pressure to be slim and of achievement expectations).

${ }^{61}$ See, e.g., Hayley K. Dohnt \& Marika Tiggemann, Body Image Concerns in Young Girls: The Role of Peers and Media Prior to Adolescence, 35 J. YouTH \& ADOLESCENCE 141 (2006) (finding that body image concerns are relevant for girls as young as five to eight years old and noting a correlation between dieting awareness and exposure to magazines promoting thinness and attractiveness by presenting underweight models); Daniel R. Anderson et al., Early Childhood Television Viewing and Adolescent Behavior: The Recontact Study, 66 
The question that arises wherever market forces shape people's preferences is why not allow the state to intervene to prevent the preference-changing effects of the market or to restore the original preferences if appropriate? Note that state intervention in such cases would reverse effects imposed by third parties rather than create new preferences. In all the contexts discussed above, it can be argued that consumers made their own choices and that the state should stay out of those choices. A strong counter-argument, however, is that when merchants exploit consumers' ignorance, irrationality, and inability to organize and shape their preferences so as to serve the merchants' interests, state intervention through the law is justified no less than when market failures facilitate consumer exploitation without changing preferences. ${ }^{62}$

\section{Preferences about Preferences}

People often have second-order preferences regarding their firstorder preferences, and they need the state's or law's assistance to satisfy the second-order preferences. ${ }^{63}$ In those cases, intervention by the state or the law could bring into a Pareto improvement: everyone is made better off and no one is made worse off. A classic illustration of the possible tension between first- and second-order preferences can be drawn from Homer's tale of Odysseus and the Sirens. ${ }^{64}$ Odysseus had a first-order preference to listen to the Sirens' song, but knew that this would lead him to his death. His second-order preference was to live. In order to satisfy the latter preference, Odysseus could have plugged his ears with beeswax, as his ship's crewmen did, and avoided hearing the Sirens' song. Instead, however, he came up with a plan that enabled him to enjoy the best of both worlds: he had his crew tie him to the ship's mast and

MONOGRAPHS SOC'Y FOR RES. CHILD DEV. 1, 116-17 (2001) (finding that viewing entertainment television, where the ideal body type for women is represented by slender fashion models and actresses, causes adolescent girls to develop a negative body image and a desire to be thinner).

62 See Daphna Lewinsohn-Zamir, Objectivity of Well-Being and the Objectives of Property Law, 78 N.Y.U. L. REV.1669, 1680-81 (2003), discussing ideal preferences as opposed to actual preferences, which might be affected by mistakes and lack of information. She suggests that arguably, ideal, rather than actual, preferences should be respected since they express the actual preferences an individual would have were she well-informed and could thoroughly deliberate all possible alternatives.

63 Sunstein, supra note 11, at 1140 (explaining the preference about preference phenomenon).

64 Homer, The Odyssey 146-47 (Walter Shewring trans., Oxford Univ. Press 1980) (c. 800 B.C.E.); JON ELSTER, SOUR GRAPES, at vi (1983); Sunstein, supra note 11 , at 1140 . 
ordered them not to untie him even if he commands them to do so. In this way, Odysseus was able to listen to the Sirens' song and stay alive.

In contrast to its originality in the context of the ancient tale, Odysseus' solution manifests itself in many situations in the real world. Anyone who has ever tried to lose weight or stop smoking, for example, will recognize this. A person could have a first-order preference to overeat or to smoke while, at the same time, a secondorder preference to avoid overeating or smoking. ${ }^{65}$ His second-order preference often motivates him to take measures to prevent being tempted by his first-order preference. Thus, a person who wants to lose weight might refrain from bringing high-calorie food into his home; likewise, a person trying to quit smoking might commit to paying his family and friends a fine if he succumbs to the temptation to smoke. Indeed, self-binding mechanisms can serve desirable goals, and a person may be willing to adopt them if they can prevent him from satisfying his undesirable (first-order) preferences. ${ }^{66}$

But when individuals are incapable of applying self-binding mechanisms, the state could assist them in facilitating their secondorder preferences, ${ }^{67}$ by intervening to change their undesirable firstorder preferences. To illustrate, imagine that many people consume drugs and cigarettes. Assume that most of them realize that they would be better off were their preferences to change; in fact, they might be quite happy were the state to intervene to effect this change. Moreover, given the opportunity, they would perhaps even call on the state to intervene. Under such circumstances, state intervention

65 See Jan Schnellenbach, Nudges and Norms: On the Political Economy of Soft Paternalism, 28 EUR. J. POL. ECON. 266, 270 (2012) (explaining the concept of meta-preferences, which are analogous to second-order preferences, with the example of "a smoker who maximizes his short-term utility by surrendering to his addiction, but whose meta-preferences are such that he would in fact prefer to be a non-smoker"). For a supporting study, see Centers for Disease Control \& Prevention, Quitting Smoking Among Adults-United States, 2001-2010, 60 MORBIDITY \& MORTALITY WKLY. REP. 1513, 1513 (2011) (analyzing data from health interview surveys conducted between 2001-2010 and finding that in 2010, $68.8 \%$ of active adult smokers wanted to stop smoking).

66 First-order and second-order preferences should be distinguished from conflicting preferences that the preference holder would try to balance between.

67 Michael Abramowicz \& Ian Ayres, Commitment Bonds, 100 GEO. L.J. 605 (2011-2012) (presenting the notion of commitment-bond mechanisms that help people or entities strongly bind themselves to their self-commitments); Saul Levmore, Internality Regulation Through Public Choice, 15 THEORETICAL INQUIRIES L. 451 (2014) (explaining the notion of self-binding regulation in the context of health and safety); Saul Levmore, From Helmets to Savings and Inheritance Taxes: Regulatory Intensity, Information Revelation, and Internalities, 81 U. CHI. L. REV. 229 (2014) (explaining self-binding regulations). 
could be justified.

Consider people's preferences to save and preferences to consume. Many consume more and save less than what their secondorder preferences entail. ${ }^{68}$ How can the state help such individuals satisfy their second-order preferences? One way would be to impose mandatory rules to save more and consume less. However, a more practical and effective way (but which would certainly generate objections) would be to change the first-order preferences (to save less and consume more) and thereby further the second-order preferences (to save more and consume less). ${ }^{69}$

Sometimes individuals have second-order collective preferences that clash with their first-order private preferences. Such a conflict requires collective action, which is often unfeasible for individuals. The state could solve this problem by changing their first-order preferences and enabling the realization of their second-order preferences. ${ }^{70}$ Take the case of organ donation. There is general consensus that both society at large and every individual person would be better-off were there widespread organ donation. Thus, (almost) all people might have a collective preference for organ donation but a private preference not to donate their own organs. If people's private preferences regarding their own organ donation could be changed by the state, this would be consistent with the collective preferences of most people. But how could the state accomplish this? One option is to change the default rule from "no donation" to "donation." This arrangement, which allows people the opportunity to opt-out of donating, has been adopted by several countries and shown to increase organ donation dramatically. ${ }^{71} \mathrm{~A}$ standard explanation for people's inclination not to opt-out of the "donation" default rule is the natural human reluctance to face

68 See, e.g., James J. Choi et al., Defined Contribution Pensions: Plan Rules, Participant Choices, and the Path of Least Resistance, in 16 TAX POLICY AND THE ECONOMY 67, 72 (James M. Poterba ed., 2002) (finding that 68\% of employees report their actual savings rate to be too low compared to their ideal rate).

${ }^{69}$ This is not the nudge that Thaler \& Sunstein advocate. See infra Section III.D.

70 See Sunstein, supra note 11, at 1140 (demonstrating the preference about preference phenomenon in the context of consumption choices and suggesting how to contend with it).

${ }^{71}$ See Cass R. Sunstein, Deciding by Default, 162 U. PA. L. REV. 1, 35 (2013-2014) (showing that a default rule in favor of organ donation can increase significantly people's willingness to be donors); Danyang Li et al., Increasing Organ Donation via Changes in the Default Choice or Allocation Rule, 32 J. HEALTH ECON. 1117, 1117-29 (2013) (showing that the way policymakers frame the default rule influences people's attitudes towards organ donation); Eric Johnson \& Daniel Goldstein, Defaults and Donations Decisions, 78 TRANSPLANTATIONS 1713 (2004) (same). 
matters related to death. ${ }^{72}$ An alternative (or perhaps supplementary) explanation is that the "donation" default rule was embraced by the public as a new norm and shaped people's first-order (private) preferences to bring them closer to their second-order (collective) preferences. $^{73}$

\section{Lack of Opportunities}

It is strongly debated in many liberal democracies whether and to what extent the state should respect the preferences of members of minority groups not to be treated equally. ${ }^{74}$ In the Jewish orthodox community, for example, women are often excluded from the public sphere. ${ }^{75}$ Should the state intervene if it is convincingly shown that most women in this community prefer such treatment, which liberal communities consider illegitimate discrimination? A plausible response is that the state should intervene regardless of the women's own preferences since the intervention would bring about desirable social change, which is more important than the women's private preferences. This claim could be supplemented by the paternalistic assertion that this social change would, in the long-run, serve the interests of the women who currently prefer to prevent the change and even resist it. ${ }^{76}$

\footnotetext{
${ }^{72}$ See Sunstein, supra note 71 , at 34 (suggesting that we think about the problem in terms of costs and benefits, for aside from the benefit to third parties, people tend to consider only the emotional costs borne by those who choose to donate their organs)

${ }^{73}$ Cf. Oren Bar-Gill \& Chaim Fershtman, Law and Preferences, 20 J. L. ECON. ORG. 331, 332 (2004) ("The broad writing on the influence of legal policy on norms and preferences has largely been founded on the symbolic or expressive impact of law. If the law says that $\mathrm{x}$ is 'bad' (or illegal), then preferences will ultimately adjust to devalue $\mathrm{x}$; and conversely, if the law says that $\mathrm{x}$ is 'good,' then preferences will adjust to value $\mathrm{x} . ")$.

${ }^{74}$ Menachem Mautner distinguishes between two central stances in the debate over the liberal state's treatment of cultural practices of non-liberal groups living within it. The first stance, whose proponents are referred to as "autonomy liberals," holds that the state ought to be activist in its relations with these groups and instill autonomy and other central liberal values in its members. The second stance, whose proponents are referred to as "diversity liberals," prefers the value of diversity to autonomy and therefore calls for "restraint" on the part of the state in its relations with non-liberal groups. Menachem Mautner, From "Honor" to "Dignity": How Should a Liberal State Treat Non-Liberal Cultural Groups?, 9 THEORETICAL INQUIRIES L. 609, 610-11 (2008).

75 See Judith Romney Wegner, Status of Women in Jewish and Islamic Marriage and Divorce Law, 5 HARV. WOMEN'S L.J. 1, 19 (1982) (presenting several examples of Jewish traditions relating to women's legal ability to perform social roles in the public domain).

76 See Gila Stopler, Countenancing the Oppression of Women: How Liberals
} 
An alternative argument for state intervention would be that the women's preferences were shaped in a world offering very limited opportunities to develop different preferences; or in other words, these women adapted their preferences to the world into which they were born. ${ }^{77}$ Therefore, their existing preferences should not be a compelling consideration against social change, and there could be particular justification for the state to intervene not only in conduct but also in the women's preferences themselves. ${ }^{78}$

Preferences that are endogenous to the prevailing legal or social order are quite common, and the exclusion of women in the Jewish orthodox community is only one example. Another is the segregation of Whites and Blacks in the United States up until about fifty years ago. ${ }^{79}$ In this context too, it was claimed that segregation was compatible with Black preferences at the time. This can also be countered, however, with the argument that those preferences were shaped in a world in which Blacks had very limited opportunities to develop other preferences. Therefore, state intervention not only in conduct but also in preferences should not be objected to. ${ }^{80}$

In other cases, it is not a lack of opportunities that produces "problematic" preferences but the availability of bad opportunities. For instance, the state's indirect encouragement of the prostitution industry is likely to lead some men to develop preferences for sex for money. Here, state intervention to change preferences should clearly be allowed, especially if those preferences are likely to adversely

Tolerate Religious and Cultural Practices That Discriminate against Women, 12 COLUM. J. GENDER \& L. 154, 184-89, 214-17 (2003), who questions the validity of religious women's willing acquiescence to their own subjugation given the flaws in their apparent consent; she calls on states to intervene in oppressive religious practices using such measures as revoking financial support and instituting mandatory education for gender equality.

77 Sunstein, supra note 11, at 1148 (discussing adaptive preferences).

78 The tale of the fox and the grapes is illustrative of the phenomenon of adaptive preferences (ELSTER, supra note 64; Sunstein, supra note 11, at 1148). The fox, unable to reach the grapes that he desired to eat, convinced himself that they were sour and, as a consequence, ceased to desire them or, in other words, adapted his preferences (although this might not be a preference change but a factual mistake).

${ }^{79}$ Sunstein, supra note 11, at 1149 (explaining how Blacks long tended to shape their preferences in accordance with the discriminatory status-quo).

${ }^{80}$ The fox and the grapes tale (see supra note 78) is not applicable to the exclusion of women and American racial segregation policy, for there is a substantive difference between being deprived of the opportunity to eat grapes and being deprived of the opportunity to live in dignity and equality. The latter is a social and political problem of the utmost importance, and thus the argument for state intervention is especially strong. $C f$. JOSEPH RAZ, MORALITY OF FREEDOM 369-99 (1988) (justifying state intervention to enhance people's individual autonomy). 
affect others. ${ }^{81}$ But there is a more general argument to be made: since any allocation of entitlements and resources in society affects people's preferences ${ }^{82}$ and since the state shapes people's preferences through these allocations, it is legitimate, in the appropriate circumstances, for it to change those preferences, which it in fact created. ${ }^{83}$ Applying this logic, the preference of Blacks, at a certain point in time, to be segregated was a product of the racial segregation and oppression imposed by the state for centuries. Why, then, should the state not be permitted to rectify what it has done by changing those preferences? Certainly, not all means of preferences change are legitimate, and sometimes the change is unjustified even if it serves an admirable goal. But the aim of this part of the article is simply to suggest that in certain circumstances, the objection to preferences change should be relaxed.

\section{E. Lack of Information and Cognitive Limitations}

There are also cases in which individuals do not lack sufficient opportunities, but their lack of information and cognitive limitations cause them to develop preferences they would not have developed given full information and full rationality. From a certain perspective, this category of cases is interrelated with the previous category: whereas the latter relates to a lack of opportunities for objective reasons, the present category involves a lack of opportunities for subjective reasons. ${ }^{84}$

Let us return to the smoking example. In the past, many individuals developed a preference to smoke because of a lack of information. Had they known the health risks from the outset, they might have refrained from smoking. ${ }^{85}$ Smoking also leads to

\footnotetext{
${ }^{81}$ Supra Section II.A.

${ }^{82}$ Consider the endowment effect: policymakers will find it hard to change the status quo since people susceptible to the endowment effect will fight harder to avoid the change than had they not been susceptible to this effect. See EYAL ZAMIR \& DORON TEICHMAN, BEHAVIORAL ECONOMICS AND THE LAW 321 (2014).

${ }^{83}$ Cf. Hanoch Dagan, Property's Structural Pluralism: On Autonomy, the Rule of Law, and the Role of Blackstonian Ownership, 3 BRIGHAM-KANNER PROP. RTS. CONF. J. 27, 33 (2014) (explaining that the state should recognize a sufficiently diverse set of robust frameworks in property rights so that people can enjoy their individual autonomy). For a similar argument in the context of contract law, see HANOCH DAGAN \& MichaEl Heller, A CHOICE THEORY OF CONTRACTS, at pt. III (forthcoming 2016).

${ }^{84}$ This category is related also to the category discussed in Section II.B. (Market Forces): in both categories, preferences develop in a particular way because of imperfections in the individual preference holders.

85 Plaintiffs in tobacco litigation commonly make the claim that the tobacco companies are liable for damages caused by their products due to their failure to
} 
addiction, and addiction (at least when it is more psychological than physical in nature) resembles a cognitive limitation: even though the individual knows what is good for him, he is incapable of pursuing that good. It might be similarly claimed that racist preferences are also the product of a lack of information and cognitive limitations, ${ }^{86}$ although clearly such preferences are motivated by other factors as well. $^{87}$

The general argument being made here is that when preferences developed due to a lack of information or cognitive limitations, the objections to the state's changing them lose much of their force. In particular, the argument that preferences changing by the state would inappropriately intervene in people's personality becomes less compelling. ${ }^{88}$

\section{F. The Collective Action Problem}

The state often intervenes in the market when individuals fail to

disclose smoking-involved risks to customers. See, e.g., American Tobacco Co. v. Grinnell, 951 S.W.2d 420, 425 (Tex. 1997); Allgood v. R.J. Reynolds Tobacco Co., 80 F.3d 168, 170 (5th Cir. Tex. 1996); Roysdon v. R.J. Reynolds Tobacco Co., 849 F.2d 230, 232 (6th Cir. Tenn. 1988). Indeed, data show that awareness of health risks decreases smoking tendencies. WORLD HEALTH ORGANIZATION, WHO REPORT ON THE GLOBAL TOBACCO EPIDEMIC, 2011, at 14 (2011).

86 See Judith H. KATZ, White AwARENESS: HANDBOOK FOR ANTI-RACISM TRAINING 10 (2d ed. 2003) (noting the concept of "white privilege," which is "often invisible to those who possess it," as a predominant factor in modern racism in the United States); Asa G. Hilliard, Foreword, in LOUISE DERMAN-SPARKS \& CAROL BRUNSON PHILlips, TEACHING/LEARNING ANTI-RACISM: A DEVELOPMENTAL APPROACH, at xi, xii (1997) (explaining the importance of education for mitigating racist tendencies).

${ }^{87}$ See, for example, Michael Banton, The Nature and Causes of Racism and Racial Discrimination, 7 INT'L SOC. 69, 77-78 (1992), who notes that exclusion, which is often associated with territorial claims, can be a possible objective of racism, as a group occupying a certain territory its members consider to be exclusively their own could become hostile towards other groups settling on that same territory. Banton also discusses stratification as a possible motivation behind racism, i.e., the desire to maintain the subordinate status of members of another group. Scientific models that were intended to account for biological differences among humans and, accordingly, developed racial classifications are viewed as a predominant cause of racism. See also Andreas Wimmer, Explaining Xenophobia and Racism: A Critical Review of Current Research Approaches, 20 ETHNIC \& RACIAL STUD. 17 (1997), who discusses and refutes commonly raised explanations for racism and focuses, instead, on the existence of a political struggle over who has the right to be cared for by the state and society in times of intensified social conflict.

${ }^{88}$ Cf. Mill, supra note 19 , at 158 (when a person is about to cross a collapsing bridge and is unaware of the risk, paternalistic intervention to save his life is justified). 
take collective action that can be expected to improve their wellbeing. To illustrate, one of the state's most important roles is to produce public goods. ${ }^{89}$ When every individual expecting to benefit from the public good refuses to share in the costs of production, hoping to free ride on other people's investments, collective action becomes impossible and state intervention necessary. ${ }^{90}$ An analogical situation warranting state intervention is when collective action is necessary to change people's preferences, but they are incapable of initiating this themselves. Such a need for collective action arises when no individual finds it beneficial to change his preferences so long as others do not do the same, and no one wants to be the first to initiate the change. In such conditions, the only way to move the group of individuals from one equilibrium to a new (perhaps better and more efficient) one is for the state to intervene in their preferences. $^{91}$

Consider the preference to live in a traditionally structured family unit. ${ }^{92}$ Satisfying this preference depends substantially on the preferences of others: so long as the majority of other people have this preference, developing a preference not to live in a family unit at

${ }^{89}$ Pure public goods are characterized by the inability to exclude people from consuming them ("non-excludability") and by the inability of one person's consumption to detract from or prevent another person's consumption ("nonrivalry"). See Joseph E. Stiglitz, Economics of the Public Sector 128-29 (3d ed. 2000).

${ }^{90}$ Paul Samuelson, The Pure Theory of Public Expenditure, 36 R. ECON. \& STAT. 387 (1954); Paul Samuelson, Diagrammatic Exposition of a Theory of Public Expenditure, 37 R. ECON. \& STAT. 350 (1955) (discussing the market's ability to provide public goods); Paul Samuelson, Aspects of Public Expenditure Theories, 40 REV. ECON. \& STAT. 332 (1958) (discussing market provision of public goods); STIGLITZ, supra note 89, at 129 (explaining how non-excludability and non-rivalry result in market failure).

91 Compare this to the category of cases in which market forces shape the preferences of consumers who cannot organize to take collective action against those effects. In such circumstances, state intervention could be justified to contend with the collective action problem. Supra Section II.B.

92 Empirical data from research conducted in the U.S. show that while the popularity of traditional family structures (namely, marriage) is declining, they are still aspired-to by the majority of Americans. See, e.g., Frank Newport \& Joy Wilke, Most in U.S. Want Marriage, but Its Importance Has Dropped, GALLUP (Aug. 2, 2013), http://www.gallup.com/poll/163802/marriage-importancedropped.aspx (finding that most Americans are either married or would like to be married someday); Millennials in Adulthood, PEW RESEARCH CENTER (Mar. 7, 2014), http://www.pewsocialtrends.org/2014/03/07/millennials-in-adulthood/ (finding that $69 \%$ of millennials would like to marry); JERALD G. BACHMAN ET AL., MONITORING THE FUTURE-QUESTIONNAIRE RESPONSES FROM THE NATION'S HigH SCHOOL SENIORS 50 (2014) (finding that having a good marriage and family life is "extremely important" to $75.9 \%$ of high-school seniors). 
all or a preference to live as a non-traditional family runs counter to every individual's interest. Note that although this recalls the lack of opportunities category of cases, ${ }^{93}$ here, what is problematic is that each and every individual has a strong interest not to change his preferences so long as other individuals don't change their preferences. Thus, whereas a lack of opportunities could be resolved through state provision of the missing opportunities, ${ }^{94}$ in the present category of cases, the state must attend to a collective action problem.

It is quite unlikely that were the state to recognize only the traditional family unit and even restrict the establishment of "new families," individuals would develop a preference not to live as a traditional family or in a family unit at all. This brings into question the claim that the state's recognition of alternative families is unjustified because most people's preferences pull in the opposite direction. Setting aside other important considerations for recognizing new families, it should be noted that preferences against the non-traditional family frameworks could be a product of the existing legal and social order, which cannot change spontaneously. ${ }^{95}$ Only state intervention, through explicit recognition of nontraditional families, can induce people to change their seemingly unalterable preferences or at least make them more tolerant and accepting of such families.

One way to understand this category of cases is as a manifestation of the conformism tendency and, perhaps, the herd effect. ${ }^{96}$ People often have a tendency to do or think exactly as others do or think, unhesitatingly. Sometimes defined as conservatism or adherence to the status quo, ${ }^{97}$ this tendency is in fact driven by a different logic: the mere fact that other people behave in a certain way seems good reason to behave in the same way. The conformism tendency could explain why people's preferences generally do not change when they are relatively homogeneous and interdependent with the preferences of others. State intervention might encourage

\footnotetext{
${ }^{93}$ Supra Section II.D.

${ }^{94}$ Infra Section III.D.

${ }^{95}$ For a general analysis highlighting the inherent difficulties in changing the legal order, which stem from the system's architecture, see Marc Galanter, Why the "Haves" Come out Ahead: Speculations on the Limits of Legal Change, 9 LAW \& SOC'Y REV. 95 (1974).

${ }^{96}$ See Abhijit Banerjee, A Simple Model of Herd Behavior, 107 Q. J. ECON. 797 (1992) (explaining people's tendency to do what everyone else does). For further analysis, see Ian Ayres \& Joshua Mitts, Anti-Herding Regulation, 5 HARV. Bus. L. REV. 1 (2015).

97 See Banerjee, supra note 96, at 802 (presenting the basic model of herd behavior).
} 
outliers to step forward and enable, in the long run, a change in the preferences of many other people. Interestingly, conformism and the herd effect can operate to make state intervention quite effective: if enough people change their preferences, a new, stable equilibrium can emerge, from which deviations will be unlikely.

\section{G. Existing versus Future Preferences}

Up to this point, we have discussed cases in which state intervention could change existing preferences. But consider now cases in which such intervention could prevent new preferences from forming. Let's return to the case of smoking: it is one thing to intervene in people's preferences to smoke and quite another to intervene to prevent people from ever developing a preference to smoke (for example, by prohibiting everyone born after 2005 from smoking). Similarly, it is one thing to intervene in people's preference for sweet or salty food, and quite another to intervene to prevent such preferences from developing in the first place or from intensifying. ${ }^{98}$

${ }^{98}$ Compare this to the debate over whether it is appropriate to show the public photographs or videos that visually depict the terrible consequences of smoking (or road accidents). For examples of studies supporting the usage of graphic warning labels on cigarette packets, see Ekant Veer \& Tracy Rank, Warning! The Following Packet Contains Shocking Images: The Impact of Mortality Salience on the Effectiveness of Graphic Cigarette Warning Labels, 11 J. CONSUMER BEHAV. 225 (2012) (finding that when compared with text-only labels, shocking visual warning labels on cigarette packets significantly increase intentions to quit or to not start smoking); Sunday Azagba \& Mesbah F. Sharaf, The Effect of Graphic Cigarette Warning Labels on Smoking Behavior: Evidence from the Canadian Experience, 15 NICOTINE \& TOBACCO RES. 708 (2013) (finding that graphic warnings have a statistically significant effect on smoking prevalence and quit attempts). For examples of opposing views, see the court ruling in R.J. Reynolds Tobacco Co. v. FDA, 696 F.3d 1205, 1219 (D.C. Cir. 2012), that FDA requirements to include graphic warning labels on cigarette packets violate the First Amendment; the court held that the "FDA has not provided a shred of evidence - much less the 'substantial evidence' required by the APA — showing that the graphic warnings will 'directly advance' its interest in reducing the number of Americans who smoke." See also Robert A.C. Ruiter \& Gerjo Kok, Letter to the Editor, Saying Is Not (Always) Doing: Cigarette Warning Labels Are Useless, 15 EUR. J. PUB. HEALTH 329 (2003) (questioning the existing evidence in favor of warning labels and arguing that these labels generate counterproductive defensive reactions); David M. Erceg-Hurn \& Lyndall G. Steed, Does Exposure to Cigarette Health Warnings Elicit Psychological Reactance in Smokers?, 41 J. APPLIED SoC. PSYCH. 219 (2011) (finding that that graphic anti-smoking warnings can elicit maladaptive psychological responses, namely, reactance, a motivation to restore freedom by, for example, rebelling against the mitigating force). It can be argued that these means are appropriate at least when directed at non-smokers in order to 
In the categories of cases discussed in this part, state intervention in people's preferences can be justified at least to some extent. But what forms of intervention would be legitimate? In Part III below, four modes of state intervention in people's preferences will be presented, each varying in terms of pervasiveness and intensity, on the one hand, and the identity of their addressees, on the other.

\section{DIFFERENT MODES OF INTERVENTION}

As noted, the ways in which the state intervenes in people's preferences can differ in pervasiveness and intensity. On the one hand, state intervention can be coercive (for example, when the state imposes duties on specific parties) and, on the other hand, it can be soft (like when the state transmits educational messages). The intervention can also differ in terms of its addressee: it could address third parties who can affect people's preferences (indirect intervention), or it could address the preference holders themselves (direct intervention).

This Part discusses four different modes of state intervention, categorized according to intensity and addressees: coercive-direct, coercive-indirect, soft-direct, and soft-indirect.

\section{A. Coercive and Direct}

The most extreme form of intervention in preferences occurs when the state forces individuals to change their preferences. While it would be an understatement to say that such intervention is undesirable, it could, nonetheless, be an option in some very rare cases. Consider, again, a sex offender, who poses a high risk to women. Say he consents to undergo medical treatment that will change his sexual preferences in return for mitigation of his sentence. In such extreme circumstances, state intervention might warrant serious consideration. ${ }^{99}$

Another prevention option-which would likely trigger less opposition - is to change people's preferences by coercing them into changing their behavior. Cognitive psychology research has shown that when people are forced to change their behavior, particularly by

deter them from smoking.

${ }^{99}$ It is questionable, however, whether this intervention is really about changing preferences and not about preventing their satisfaction. 
way of light sanctions, they may also eventually change their preferences. ${ }^{100}$ Thus, imposing a light sanction for smoking could be an effective means of changing people's preference to smoke. ${ }^{101}$ In Part II, we saw that a lack of appropriate opportunities prevents people from developing certain preferences because they adapt their preferences to the available opportunities. ${ }^{102}$ To extend this claim, if people lack the opportunity to smoke (assuming they are law-abiding citizens), then presumably they will adapt their preferences and abandon any preference to smoke.

The reverse is also possible, however: sometimes the unavailability of opportunities can intensify rather than repress preferences or simply have no effect on them at all. ${ }^{103}$ The U.S. Prohibition era is illustrative of this phenomenon. The ban on selling, manufacturing, importing, and transferring alcohol ${ }^{104}$ did not alter people's preferences to consume alcohol, but quite the contrary: for many, it in fact intensified those preferences. ${ }^{105}$ In contrast, for people who have yet to develop such preferences (e.g., people who are only potential alcohol consumers or potential smokers), eliminating the opportunities to consume alcohol or to smoke could be a very effective way to prevent those preferences from ever forming. 106

\section{B. Coercive and Indirect}

As noted, consumers' preferences are often shaped by market forces. Preferences for over-consumption and preferences for being in constant social contact are just two examples that illustrate how merchants use their power to change people's preferences to serve merchants', rather than consumers', interests. ${ }^{107}$ One way for the state to intervene in consumers' preferences is to restrain the market forces and their effect on those preferences. Accordingly, when merchants engage in tactics that are likely to radically change

\footnotetext{
100 See Lewinson-Zamir, supra note 13, at 58 (arguing that mild sanctions are likely to reinforce voluntary compliance).

${ }^{101}$ See Sunstein \& Thaler, supra note 3, at 232 (explaining how small nudges can help people quit smoking).

102 Supra Section II.D.

103 Sunstein, supra note 11, at 1143 (explaining how banning consumption of a certain undesirable good could induce people to make even worse choices).

104 The National Prohibition Act, 41 STAT. 305 (1919).

105 Jack S. Blocker, Did Prohibition Really Work?, 96 AM. J. PuB. HEALTH 233, 238 (2006) (presenting the effects of the National Prohibition Act on Americans' drinking habits).

${ }^{106}$ Supra Section II.G.

107 Supra Section II.B.
} 
consumers' preferences, the state should treat the merchants' motives with suspicion and intervene in the appropriate cases, just as it does when merchants exploit consumers' lack of information, irrationality, or inability to organize themselves. This is indirect, albeit coercive intervention since it is directed not at the preference holders but at those who could shape the preferences.

Another type of coercive indirect intervention arises when the state addresses third parties and directs them to create, or not to inhibit, opportunities ${ }^{108}$ that are essential for new preferences to develop. Take, for example, the resistance of ultra-orthodox Jews to liberal arts and science studies for their children. ${ }^{109}$ This attitude is probably a manifestation of the parents' genuine preference to avoid exposure to secular studies; this, in turn, is likely the product of the lack of opportunities in their communities, ${ }^{110}$ the social structure into which they are locked from birth, or the values they were instilled with in their community. ${ }^{111}$ The state could intervene by forcing the

\footnotetext{
${ }^{108}$ Supra Section II.D.

109 For a brief historical account of the attitude within ultra-orthodox Jewish communities towards secular studies, see JACOB LUPU, NEW DIRECTIONS IN HAREDI SocIETY IN ISRAEL: VocATIONAL TRAINING AND ACADEMIC STUdIES 1012 (2005). For current objections, see, e.g., David Rosenberg, New York UltraOrthodox Are Following Israel's Bad Example, HAARETZ (Nov. 26, 2014), http://www.haaretz.com/blogs/david-s-harp/.premium-1.628581 (describing parents' objections to an attempt to promote general education studies such as English and math in ultra-orthodox New York schools); Ronny Linder-Ganz, New Generation of Ultra-Orthodox Men Going from Religious to Nursing Studies, HAARETZ (Jun. 2, 2015), http://www.haaretz.com/israel-news/business/.premium1.659011 (describing the barriers to entering the labor force for ultra-orthodox Jews due to the stress on religious studies in the ultra-orthodox community, which results in the discontinuation of math and English studies at a very young age).

${ }^{110}$ See, e.g., Jeremy Sharon, Haredi Yeshiva with Radical Agenda to Provide High School, Higher Education Courses, JERUSALEM POST (June 28, 2015), http://www.jpost.com/Israel-News/Haredi-yeshiva-with-radical-agenda-to-providehigh-school-higher-education-courses-407347 (discussing the lack of exposure to secular studies within the ultra-orthodox Jewish community and discussing examples of adolescents who have had no access to such knowledge in the community's education system for many years).

111 See, e.g., Rosenberg, supra note 109 (suggesting that a reason for ultraorthodox Jews' resistance to a conventional career path could be their common prioritization of religious requirements over conventional cost-benefit analysis, as is evident in the high birthrate in the community); LUPU, supra note 109, at 11 ("The right to study Torah for its own sake became an overriding obligation, pushing aside the concern for material well-being."); Jeremy Sharon, Shteinman: No Secular Studies in Haredi Education, JERUSAlEM POST (May 7, 2013), http://www.jpost.com/Jewish-World/Jewish-News/Shteinman-No-secular-studiesin-haredi-education-312302 (citing a prominent spiritual leader in the Jewish ultraorthodox world who vehemently opposes secular studies).
} 
parents to provide their children with secular instruction, in the hope that this will change the parents' preferences in the long run. This would be coercive and direct intervention in people's preferences. Alternatively, the state could force the community's religious leaders or institutions to make secular studies available to its members. ${ }^{112}$ Eventually, more and more members of the community would be exposed to such studies and change their preferences accordingly. This would constitute coercive but indirect intervention in people's preferences: it would not be coercive towards the preference holders but, rather, towards those who can impact their preferences.

\section{Soft and Direct}

Soft and direct state intervention in people's preferences is the most common form of intervention. Education, in which the state is often an active player, shapes values and changes preferences. ${ }^{113}$ The law, as an agent of the state, sometimes performs an expressive and educational function. ${ }^{114}$ Constitutions shape value preferences (for equality, dignity, etc.), as do court decisions occasionally. ${ }^{115}$ And as some commentators have noted, criminal law has an expressive function too. ${ }^{116}$ Take, for example, laws prohibiting sexual

112 See LuPU, supra note 109 , at 50, who discusses the strong impact of religious leaders' views regarding secular studies on the attitudes of their communities. For a study demonstrating the influence of religious leaders in the ultra-orthodox Jewish community on members' personal decisions, see Kate Coleman-Brueckheimer et al., Involvement of Rabbinic and Communal Authorities in Decision-Making by Haredi Jews in the UK with Breast Cancer: An Interpretative Phenomenological Analysis, 68 Soc. SCI. \& MED. 323 (2009).

${ }^{113}$ It is questionable whether educational intervention in preferences is necessarily soft. In extreme cases, it will be more "brainwashing" than education.

114 See generally RICHARD H. MCADAMS, THE EXPRESSIVE POWERS OF LAW (2015) (discussing, among other things, how the law creates "focal points" and reveals information to people and the courts).

115 See David A. Dana, The Law and Expressive Meaning of Condemning the Poor After Kelo, 101 Nw. U. L. REV. 365, 378 (2007) ("Laws do not simply, or only, dictate what people and institutions are permitted or prohibited from doing. Laws are also a part of the culture that helps form prevailing values and understandings."); Robert C. Post, The Supreme Court, 2002 Term-Foreword: Fashioning the Legal Constitution: Culture, Courts, and Law, 117 HARV. L. REV. 4, 8 (2003) (arguing that "constitutional law and culture are locked in a dialectical relationship, so that constitutional law both arises from and in turn regulates culture," and defining "culture" as "the beliefs and values of nonjudicial actors"); Holly Doremus, Constitutive Law and Environmental Policy, 22 STAN. ENVTL. L.J. 295, 307-18 (2003) (discussing how the law reinforces and shapes values).

116 Alon Harel \& Ariel Porat, Aggregating Probabilities Across Cases: Criminal Responsibility for Unspecified Offenses, 94 MINN. L. REV. 261, 303-07 (2009) (discussing the expressive justifications for criminal sanctions). See also Joel 
harassment in the workplace. On the one hand, these laws are coercive: they prohibit certain types of behavior and ideally change the preferences of harassers and potential harassers in the long run. ${ }^{117}$ Even more interesting, however, is that these laws can also affect the preferences of people who are not harassers or potential harassers, by conveying feminist messages in a direct but soft way to all. ${ }^{118}$

Moreover, the state can take soft and direct interventionary measures when a lack of opportunities or collective action problem prevents people from forming new preferences. ${ }^{119}$ The state can thus assist individuals who are already considering changing their preferences. For example, by offering subsidies to ultra-orthodox Jews who are willing to move to a secular neighborhood or to secular families willing to move to an ultra-orthodox neighborhood, the state would be encouraging people to consider opportunities that were previously unavailable to them, thereby creating the potential for preferences change. While the geographical move in this example would stem from external financial incentives, the introduction of a previously unavailable opportunity could have the additional effect of altering the target group's internal preferences.

In addition, soft and direct intervention might also be suitable when people have preferences about preferences. ${ }^{120}$ In such cases, people are aware that a first-order preference they hold is inconsistent with a second-order preference. At times, the state could

Feinberg, The Expressive Function of Punishment, in DOING AND DESERVING 95, 98 (1970) (punishment is a unique tool used by society to express its disapproval of a wrongful act); Jean Hampton, The Moral Education Theory of Punishment, 13 PHIL. \& PUB. AFF. 208, 212 (1984) (arguing that punishment is intended to teach the wrongdoer that the wrongful act is forbidden because it is morally wrong).

117 Chris Diffee, Going Offshore: Horseplay, Normalization, and Sexual Harassment, 24 COLUM. J. GENDER \& L. 302, 368-69 (2013) (referring to the expressive function of sexual harassment law, which delegitimized behavior previously considered legitimate by some, and asserting that "[a]ltering the legal and cultural significance of conduct may in fact prove to be one of the most effective means of halting the conduct itself").

${ }^{118}$ Richard Mullender, Racial Harassment, Sexual Harassment, and the Expressive Function of Law, 61 MoD. L. REV. 236, 240 (1998) ("The RRA [Race Relations Act] and the SDA [Sex Discrimination Act] send out messages to the effect that discrimination on the grounds with which they are respectively concerned is wrongful."); Danielle Keats Citron, Law's Expressive Value in Combating Cyber Gender Harassment, 108 MiCH. L. REV. 373, 408 (2009) ("When court rulings declared sexual harassment a manifestation of women's inequality in the workplace, they changed its social meaning. Courts sent the message that sexual abuse in the workplace violated women's equality in a manner that would not be tolerated.").

119 Supra Sections II.D-F.

${ }^{120}$ Supra Section II.C. 
assist them in resolving this tension by offering them self-binding mechanisms that would make the satisfaction of their second-order preferences more feasible. In some circumstances, the state could go even further, say, by offering to subsidize gastric-banding surgery for obese people, which would counteract their overeating preferences. $^{121}$

\section{Soft and Indirect}

The Thaler \& Sunstein "nudge" idea exemplifies soft and indirect state intervention. In their book Nudge, they argued that the state can often change people's behavior not only through coercive intervention but also by "nudging" them to do what the state wants them to do, while leaving them with the ultimate choice of whether or not to do it. Thaler \& Sunstein call their theory "LibertarianPaternalism"122_paternalism because the nudge pushes people into doing what the state considers to be for their good and libertarian because the choice of what to do remains in the hands of the individual. Although nudging generally exploits people's cognitive limitations, this is to a virtuous end according to Thaler \& Sunstein. In some circumstances, however, the nudge in fact neutralizes people's cognitive limitations that would have otherwise led them in the wrong direction. An example of such nudging is the default rule implemented in most countries, under which a certain amount of a worker's wages is transferred to a pension fund unless she explicitly opposes this. This rule encourages, rather than obliges, saving for retirement; anyone can opt out of the default if she so desires. ${ }^{123}$ Yet the majority of people submit to the default rule, due to either the status quo bias ${ }^{124}$ or the omission bias. ${ }^{125}$ This context illustrates how the nudge uses people's cognitive limitations to direct them to what the state deems to be good for them (since if they were to forego the

\footnotetext{
121 It can be argued, however, that the operation impacts the satisfaction of the preference as opposed to its very existence.

122 Thaler \& Sunstein, supra note 3, at 4-6 (explaining that libertarian paternalism is aimed at preserving individual freedom of choice). For criticism of Thaler $\&$ Sunstein's libertarian-paternalism, see Arad \& Rubinstein, supra note 21, at 2-3 (presenting several points of criticism, including lack of transparency of preferences change policies, difficulties of verifying how different individuals perceive their own welfare, and the slippery slope concern, which leads to greater state intervention in individuals' private lives).

123 Thaler \& Sunstein, supra note 3, at 108-09.

124 See ZAMIR \& TEICHMAN, supra note 82, at 674 (discussing the status-quo bias in the context of judicial decision-making).

125 ZAMIR \& TEICHMAN, supra note 82, at 71 (arguing that omission bias is the tendency to judge harmful acts as worse than no-less-harmful omissions).
} 
payments to a pension fund, they would save less and consume more, which is assumed to be contrary to their interests). From a different perspective, the nudge here can be said to neutralize the common cognitive limitation of over-optimism, or the optimism bias. ${ }^{126}$ If people fail to save money for a rainy day because they are overoptimistic about their future needs, the nudge pushes them into doing what they would not have done because of their cognitive limitation. It has also been proposed that nudging be applied to lead people to act in society's best interests. ${ }^{127}$ For example, a default rule of assumed organ donation unless the deceased explicitly indicated otherwise would result in more organ donations to the benefit of all, as compared to a default rule that requires explicit consent to being an organ donor. ${ }^{128}$

Thaler \& Sunstein applied their idea of nudging to changing people's behavior. Could this idea be extended to changing preferences? I believe it could. ${ }^{129}$ First, the law could nudge people into behaving in a certain way that would ultimately lead to a change in their preferences as well. ${ }^{130}$ The second and more interesting option would be for the nudge to be used to impact preferences without directly affecting behaviours.

To see how this second alternative can work, let's return to the preferences of ultra-orthodox Jews against exposing their children to secular studies. Assuming these preferences were shaped partially due to a lack of opportunities to develop other preferences, ${ }^{131}$ the state's mere provision of the missing opportunities would constitute a nudge towards considering replacing the old preferences with new ones. Thus, making public colleges and universities more accessible to ultra-orthodox Jews could, in the long run, bring about a change in their preferences regarding their children's education. In Israel, for

\footnotetext{
${ }^{126}$ For a discussion of the optimism bias in relation to consumer conduct, see BarGill, supra note 54, at 22-23.

127 See Thaler \& Sunstein, supra note 3 (discussing the idea of nudging people in order to change their behavior in relation to protecting the environment).

128 Sunstein, supra note 71, at 42-43 (different default rules regarding organ donation could increase people's willingness to be donors).

129 The nudging idea has been criticized for being manipulative. See, e.g., T. M. Wilkinson, Nudging and Manipulation, 61 POL. STUD. 341 (2013) (differentiating between varying forms of nudges and concluding that some forms are prone to "manipulate and infringe upon the target's autonomy" and therefore "hard to justify"); Glaeser, supra note 31, at 155 (describing the government bureaucracy entailed by soft paternalism as "skilled in manipulating beliefs" and raising concerns about the abuse of such mechanisms). In contrast, my proposal to apply nudging to preferences is not manipulative.

${ }^{130}$ Supra Section II.A.

${ }^{131}$ Supra Section II.D.
} 
example, universities hesitate over whether to allow gendersegregated classes for ultra-orthodox Jewish students. ${ }^{132}$ There are certainly good arguments against doing this, but one advantage, which should not be easily dismissed, is that it would make higher education more feasible for the ultra-orthodox community and provide its members with the opportunities they currently lack when forming their preferences. Note that in this example, as opposed to Thaler \& Sunstein's nudging context, there is no manipulation involved: people would be offered previously-unavailable opportunities that are essential for shaping their preferences.

Another soft and indirect way to change people's preferences is through a "natural selection," or evolutionary, process. ${ }^{133}$ This approach lies on the borderline between indirectly changing preferences by directly changing behavior and directly changing preferences: the law creates the conditions in which it is easier, or more attractive, for people to develop "desirable" preferences, and thus, more and more people eventually do develop them. To illustrate, suppose that the law tends to oblige lawyers to behave altruistically towards their clients. We can therefore expect that this will lead to people with an altruistic bent to be more attracted to becoming lawyers than other people are. Alternatively, suppose that we want people who care significantly more about their social contribution than their income to be our judges or doctors. In order to attract the people with the "right" preferences, then, judges' and doctors' salaries should not be set too high. ${ }^{134}$

Note that in these examples, the law does not change people's preferences but instead creates conditions that makes certain professions more attractive to people with certain preferences. It is quite possible, however, that the more the state, or the law, makes certain professional fields appealing to people with certain preferences, the more people will develop such preferences. This would occur particularly if the attraction to a given field were to depend not only on the preference considered most essential to that

\footnotetext{
132 HCJ 6667/14, Tirosh v. Council for Higher Education (Nevo, March 19, 2015) (Isr.) (an appeal to the Israel High Court of Justice against government funding of gender-segregated classes at public universities).

133 Cf. Oren Bar-Gill \& Chaim Fershtman, Public Policy with Endogenous Preferences, 7 J. PUB. ECON. THEORY 841 (2005) (explaining how monetary incentives might induce changes in people's internal preferences); Bar-Gill \& Fershtman, supra note 73 (making a similar argument in a contractual context).

${ }^{134}$ See Stephen J. Choi, Mitu G. Gulati \& Eric A. Posner, Are Judges Overpaid? A Skeptical Response to the Judicial Salary Debate, 1 J. LEGAL ANALYSIS 47, 56 (2009) (arguing that increased salaries will attract more people to the judiciary but lower salaries will attract more suitable people, namely, those who wish to serve as judges unrelated to salary or social status).
} 
field but on other preferences as well. Thus, if enjoyment of legal challenges is the appeal for many people to being a judge but the salary is low, more and more lawyers who are attracted to the judiciary for this particular reason will develop preferences for making a social contribution and thereby compensate themselves for the non-appeal of the low salaries.

\section{CONCLUSION}

In Part II, I presented categories of cases in which the usual objections to state intervention in people's preferences weakens, while Part III examined four different ways in which the state can intervene in preferences in such cases. The discussions in the two parts, when combined, arguably provide an answer to the question of when it might be desirable for the state to intervene in preferences. This response accounts for and contends with the general arguments discussed in Part I against state intervention: personal freedom, abuse of power, the role of the state, and uncertainty.

The personal freedom argument falters in all categories of cases discussed in Part II. When preferences create a risk of the imposition of negative externalities on third parties, the personal freedom argument is less compelling, since externalities is a common justification for the law to intervene and curtail risk creators' freedom. When state intervention is aimed at preventing market forces from shaping people's preferences, the state is acting to eliminate effects created by third parties rather than to create new preferences. Therefore, such intervention can hardly be considered an infringement on consumers' freedom, for if anything, it enhances their freedom. When intervention promotes people's second-order preferences at the expense of discouraging their first-order preferences, the state is not infringing on people's freedom but rather assisting them in achieving their goals. In such cases the preferences change is a Pareto improvement: everyone is made better off and no one is made worse off. Preferences that were shaped due to a lack of opportunities or cognitive limitations are not authentic in the deep sense and were not genuinely created by an autonomous individual. Thus, state intervention in such instances is aimed at placing the individual in the position he would have occupied had the missing opportunities been available to him from the outset and had he been rational and adequately informed. Finally, when the state intervenes in preferences in response to a collective action problem, it is in no way certain that non-intervention would serve individual freedom better than the intervention does. On the contrary: soft intervention might enable individuals to shape their preferences more freely than they would absent the intervention.

The other three arguments against state intervention in 
preferences should be closely examined in each individual case that raises a need for the state to change people's preferences. Thus, I will comment only briefly on each of them. As to the arguments relating to the abuse of power and the role of the state, the concerns on which they are anchored do not differ much from similar concerns about state intervention in people's choices and behavior. The risk of abuse of power particularly diminishes when the state intervention is soft and indirect (for example, when the state makes available opportunities that were unavailable when people formed their preferences). The uncertainty argument, for its part, is not a valid concern in the many instances in which it is quite clear what the change in preferences will bring about (for example, when changing racist preferences or preferences not to smoke). ${ }^{135}$

The state intervenes - either through the law or by other means - to change people's preferences on a regular basis. Individuals and, perhaps, also legislators and public officials, are only rarely aware of the effects of state intervention on preferences. Since state intervention in preferences is so widespread, it would be far better that it be done explicitly and transparently. This would make the intervention open to both public debate and judicial scrutiny, which would be consistent with liberal democratic principles.

\footnotetext{
${ }^{135}$ Supra Section II.A.
} 